\title{
Yield, Per Day Productivity and Quality of Banana (Musa paradisica L.) Influenced by Different Varieties and Planting Materials under Middle Gujarat Climatic Condition
}

\author{
H.C. Parmar*, Vinod B. Mor and Sunil R. Patel \\ Agriculture Research Station, College of Agriculture, Anand Agricultural University, \\ Jabugam-391 155, India \\ *Corresponding author
}

Keywords

Banana, Varieties, Planting materials, Yield, Quality, Per Day Productivity

Article Info

Accepted:

04 December 2018

Available Online:

10 January 2019
A B S T R A C T

An experiment entitled was conducted at the Agricultural Research Station, AAU, Jabugam which comes under Middle Gujarat Agro-Climate Zone-III during seasons of the year 2013-14 and 2014-15 on "Evaluation of different varieties of banana in tribal area of Chhotaudepur Region of Middle Gujarat". The experiment consisted of eight treatment combinations comprised of four varieties (viz. $\mathrm{V}_{1}$. Grand Naine, $\mathrm{V}_{2}$. Robusta, $\mathrm{V}_{3}$. Mahalaxmi and $\mathrm{V}_{4}$.William) and two planting materials (viz. $\mathrm{P}_{1}$. Tissue culture plants and $\mathrm{P}_{2}$. Suckers), and conducted in RBD with factorial concept with four replications. The soil of the experimental field was sandy loam in texture. All the plants were planted at $1.80 \mathrm{~m}$ spacing with one plant per hole. Willium registered the highest yield among all in pooled analysis and it was at par with Grand naine during 2014. On pooled basis, willium variety also showed better pulp: peel ratio, where with regard to the PLW ratio, Mahalaxmi and Willium were at par and recorded higher PLW ratio. Variety Grand Naine produced significantly higher production per day (206 kg/ha) in pooled analysis, which was at par with variety Willium (203 kg/ha). Banana raised through tissue also produced higher yield, PLW ratio and per day productivity $(211.2 \mathrm{~kg} / \mathrm{ha})$ than suckers.

\section{Introduction}

Banana is the largest produced and maximum consumed amongst the fruits cultivated in India. It is known as the 'common man's fruit'. It is highly nutritive and very delicious. Banana is known as apple of paradise. In India, banana is fourth important food crops in terms of gross value and is exceeded only by paddy, wheat and milk products. Globally banana production was 145 million tonnes during 2012-13. India is the largest banana consumer and producing country in the world followed by Brazil, contributing about 20 per cent of the total world production (www.worldlistmania.com). Among the fruits, banana holds first position in production and productivity in India. It ranks second in area after mango. In India, annual production of banana is 26.51 million tonnes from an area of 7.76 lakh hectare with the productivity of 34.16 ton/ha spread all over the country (Dept. 
of Agri. \& cooperation, 2013). Banana covers 12.50 per cent of the total area under fruits, contributing nearly one third of total fruit production in the country. In India, Tamil Nadu, Karnataka, Andhra Pradesh, Maharashtra, and Gujarat are the leading banana producing states. The highest productivity is 66.0 tones/ha in Madhya Pradesh followed by Gujarat 64.09 t/ha in the year 2012-13. Area and Production of banana in Gujarat state were 67.02 thousand ha and 4.3 million metric tonnes, respectively (Dept. of Agri. \& cooperation, 2015). In Gujarat, Bharuch district had maximum area (15420 ha) and production (1.08 million metric tonne) followed by Anand and Vadodara district (Directorate of economics and statistics, Govt. of Gujarat, Gandhinagar, 2015).

Banana is perennial which produce succeeding generations of crop. The first cycle after planting is called the plant crop or mother crop. The ratoon or a lam is the sucker (also called the follower) succeeding the harvested plant.

During the past two decades the large-scale cultivation of this fruit crop has undergone considerable changes. Banana is perhaps one of the major crops, which has accepted tissue culture as a mode of propagation especially in India. Shorter harvest times and enhanced yields have popularized the cultivation of this fruit crop with respect to the area of cultivation and production by tissue culture methods.

Commercially, bananas are classified as dessert types and culinary types. The culinary types have starchy fruits and are used in the mature unripe form as vegetables. Important cultivars include Dwarf Cavendish, Robusta, Maha laxmi, William, Monthan, Poovan, Nendran, Red banana, Nyali, Safed Velchi, Basrai, Ardhapuri, Rasthali, Karpurvalli, Karthali and Grand Naine etc. Grand Naine, an imported variety from Israel is gaining popularity and may soon become the most preferred variety due to its tolerance to abiotic stresses and good quality bunches. Fruit develops attractive uniform yellow colour with better shelf life \& quality than other cultivars.

Fruits and vegetables are an important component of a healthy diet. Some fruits like bananas offer great medical benefits. This is partly because bananas aid in the body's retention of calcium, nitrogen, and phosphorus, all of which work to build healthy and regenerated tissues. Main objective of this study was standardization of the yield potential with quality under different varieties with different planting materials.

\section{Materials and Methods}

An experiment entitled "Evaluation of different varieties of banana in tribal area of Chhotaudepur Region of Middle Gujarat" was conducted at the Agricultural Research Station, Anand Agricultural University, Jabugam which comes under Middle Gujarat Agro-Climate Zone-III during seasons of the year 2013-14 and 2014-15. The experiment consisted of eight treatment combinations comprised of four varieties (viz. $\mathrm{V}_{1}$. Grand Naine, $\quad \mathrm{V}_{2}$.Robusta, $\mathrm{V}_{3}$.Mahalaxmi and $\mathrm{V}_{4}$.William) and two planting materials (viz. $\mathrm{P}_{1}$. Tissue culture plants and $\mathrm{P}_{2}$. Suckers), and conducted in RBD with factorial concept with four replications. The soil of the experimental field was sandy loam in texture, low in OC\% and available $\mathrm{N}$, medium in available $\mathrm{P}_{2} \mathrm{O}_{5}$ and $\mathrm{K}_{2} \mathrm{O}$. All the plants were planted at $1.80 \mathrm{~m}$ spacing with one plant per hole. Sowing date of banana in 2013-14 and 2014-15 was 01-082014 and 07-08-2015, respectively. Each plant of banana was fed with $10 \mathrm{~kg}$ FYM; $200 \mathrm{~g} \mathrm{~N}$; $100 \mathrm{~g} \mathrm{P}_{2} \mathrm{O}_{5} ; 200 \mathrm{~g} \mathrm{~K}_{2} \mathrm{O}$ (Recommended dose of NPK g/plant). Complete dose of phosphorus, potassium and 20 per cent nitrogen were 
applied as basal while remaining dose of nitrogen applied as four equal split of $20 \%$ at 30, 60, 90 and 120 days after monsoon. Yield (t/ha) was recorded at the time of bunch harvesting, while Pulp: peel ratio and PLW (physiological loss weight in g) ratio were also had been taken after harvesting of banana. Per day Productivity of banana calculated by below formula.

Per Day Productivity $(\mathrm{kg} /$ day $)=\frac{\text { Total Yield }(\mathrm{kg} / \mathrm{ha})}{\text { Days to maturity }} \times 100$

\section{Results and Discussion}

\section{Effect of varieties}

Data presented in table indicates that different varieties also differed significantly among themselves in respect of yield and quality parameters like pulp: peel and PLW ratio. Among different varieties tested Willium registered the highest yield among all during individual years and in pooled analysis. It was however at par with Grand naine during 2014. On pooled basis, this variety also showed better pulp: peel ratio as compared to other varieties. With regard to the PLW ratio, Mahalaxmi and Willium were at par and recorded higher PLW ratio as compared to rest of the varieties in pooled analysis. In case of per day productivity of banana, Variety Grand naine produced significantly higher production per day $(206 \mathrm{~kg} / \mathrm{ha})$ in pooled analysis, which was at par with variety Willium $(203 \mathrm{~kg} / \mathrm{ha})$.

\section{Effect of planting materials}

Plant height, plant girth, leaves per plant and finger length were significantly influenced by planting materials during both the years and in pooled analysis. Whereas, number of hand per bunch and finger girth were influenced due to planting materials during one out of two years and pooled analysis (Table 1 and 2).

Table.1 Yield and per day productivity of banana varieties as influenced by different planting materials

\begin{tabular}{|c|c|c|c|c|c|c|}
\hline \multirow[t]{2}{*}{ Varieties } & \multicolumn{3}{|c|}{ Yield, t/ha } & \multicolumn{3}{|c|}{ Per day productivity, kg/ha } \\
\hline & 2014 & 2015 & Pooled & 2014 & 2015 & Pooled \\
\hline V1 : Grand naine & 76.70 & 77.35 & 77.03 & 205.4 & 206.6 & 206.0 \\
\hline V2 : Robusta & 68.51 & 72.24 & 70.37 & 181.6 & 191.9 & 186.7 \\
\hline V3 : Mahalaxmi & 66.92 & 75.62 & 71.27 & 173.1 & 193.6 & 183.4 \\
\hline V4 : William & 79.62 & 84.20 & 81.91 & 196.4 & 209.5 & 203.0 \\
\hline S.Em. \pm & 1.32 & 2.32 & 1.33 & 3.55 & 6.11 & 3.53 \\
\hline C.D.0.05 & 3.87 & 6.81 & 3.80 & 10.43 & 17.96 & 10.08 \\
\hline \multicolumn{7}{|l|}{ Planting materials } \\
\hline P1: Tissue & 78.90 & 81.60 & 80.25 & 206.8 & 215.5 & 211.2 \\
\hline P2: Suckers & 66.97 & 73.11 & 70.04 & 171.4 & 185.3 & 178.3 \\
\hline S.Em. \pm & 0.93 & 1.64 & 0.94 & 2.51 & 4.32 & 2.50 \\
\hline C.D.0.05 & 2.74 & 4.81 & 2.69 & 7.38 & 12.70 & 7.13 \\
\hline Sig. Interaction & - & - & - & - & - & - \\
\hline C.V.\% & 5.11 & 8.46 & 7.09 & 5.31 & 8.62 & 7.25 \\
\hline
\end{tabular}


Table.2 Quality parameters of banana varieties as influenced by different planting materials

\begin{tabular}{|c|c|c|c|c|c|c|}
\hline \multirow[t]{2}{*}{ Varieties } & \multicolumn{3}{|c|}{ Pulp : Peel Ratio } & \multicolumn{3}{|c|}{ PLW Ratio } \\
\hline & 2014 & 2015 & Pooled & 2014 & 2015 & Pooled \\
\hline V1 : Grand naine & 3.06 & 3.21 & 3.14 & 10.94 & 10.83 & 10.88 \\
\hline V2 : Robusta & 2.94 & 2.99 & 2.96 & 11.43 & 11.32 & 11.37 \\
\hline V3 : Mahalaxmi & 3.05 & 3.20 & 3.12 & 12.96 & 13.35 & 13.16 \\
\hline V4 : William & 3.27 & 3.42 & 3.34 & 12.99 & 12.88 & 12.94 \\
\hline S.Em. \pm & 0.08 & 0.09 & 0.06 & 0.38 & 0.47 & 0.30 \\
\hline C.D.0.05 & 0.22 & 0.26 & 0.17 & 1.11 & 1.39 & 0.86 \\
\hline \multicolumn{7}{|l|}{ Planting materials } \\
\hline P1: Tissue & 3.10 & 3.23 & 3.17 & 11.61 & 11.62 & 11.62 \\
\hline P2: Suckers & 3.05 & 3.18 & 3.11 & 12.55 & 12.60 & 12.56 \\
\hline S.Em. \pm & 0.05 & 0.06 & 0.04 & 0.27 & 0.33 & 0.21 \\
\hline C.D.0.05 & NS & NS & NS & 0.79 & NS & 0.61 \\
\hline Sig. Interaction & - & & YP & - & - & - \\
\hline C.V.\% & 7.00 & 7.69 & 7.38 & 8.87 & 11.04 & 10.01 \\
\hline
\end{tabular}

Banana raised through tissue recorded higher values of all these traits as compared to that raised through suckers. Banana raised through tissue required less number of days to attained flowering and maturity as compared to that raised through suckers during both the years and in pooled analysis. Banana raised through tissue also produced higher yield as compared to that raised through suckers during both the years and in pooled analysis. Plant materials did not show any significant effects pulp: peel ratio but it had significant on PLW ratio in one out of two years and in pooled analysis. In general, banana raised through tissue recorded lesser PLW ratio as compared to banana raised by suckers. Banana raised through tissue culture plant, which found significantly the highest per day productivity $(211.2 \mathrm{~kg} / \mathrm{ha}$ ) than suckers.

\section{Interaction effects}

Interaction YP and YVP were found significant in case of number of leaves per plant in pooled analysis. Where, interaction between variety and planting material was found significant in case of days to flowering and maturity. Interactions YV and YP were also found significant with respect to days to flowering and maturity.

In conclusion, for getting higher yield with per day productivity of banana, variety Grand Naine planting through tissue culture plant.

\section{References}

http://r0.unctad.org/infocomm/anglais/banana /market.htm

Islam, M. S. 1998. Storage life and quality of banana as affected by packaging and coating materials. M.S. thesis, Institute of Postgraduate Studies in Agriculture, Salna, Gazipur, Bangladesh.

Natesh B.B., Aravindakshan M. and Valsalakumari P.K. (1993). Effect of split application of fertilizers in banana Musa ABB 'Nendran'. South Indian Hort. 41: 67-73.

Nascimento, W.M.O. et al., Selection of progenies of yellow passion fruit (Passiflora edulis $\mathrm{f}$. flavicarpa) to fruit 
quality. Brazilian Journal of Tropical Fruits, 25:186-188, 2003.

Patil K B and Rawale K P (2009) Pre and post harvest management of banana for domestic and export market, in the Proceedings of Second National Conference on Production of Healthy Planting Material in Banana, held during October 3 - 6, 2009 at Jalgaon MS.

Post harvest profile of banana: 2015, Department of Agriculture and Cooperation, Ministry of Agriculture, Govt. of India, pp 4-12 (2015).

Rangana, S. (1979). Manual of analysis of fruit and vegetable products. Tata
McGraw Hill Publishing Company Limited, NEW DELHI, INDIA.

Singh, H. P., Uma, S., Selvarajan, R. and Karihaloo, J. L (2011). Micropropagation for production of quality banana planting material in Asia-pacific. Asia-Pacific Consortium on Agricultural Biotechnology (APCoAB), New Delhi, India. P. 3.

Venkata Subbaiah, K., Jagadeesh, S. L., Reddy, Sathyanarayana and Kanamadi, V. C.. Effect of varieties and pretreatments on physico-chemical and sensory quality of banana. Karnataka $\mathrm{J}$. Agric. Sci.,26 (1): (115-118) 2013.

\section{How to cite this article:}

Parmar, H.C., Vinod B. Mor and Sunil R. Patel. 2019. Yield, Per Day Productivity and Quality of Banana (Musa paradisica L.) Influenced by Different Varieties and Planting Materials under Middle Gujarat Climatic Condition. Int.J.Curr.Microbiol.App.Sci. 8(01): 213-217. doi: https://doi.org/10.20546/ijcmas.2019.801.023 